\title{
Layering and parallel policy making - Complementary concepts for understanding implementation challenges related to sustainable mobility
}

Karolina Isaksson, Hans Antonson and Linnea Eriksson

Journal Article

\section{Tweet}

N.B.: When citing this work, cite the original article.

Original Publication:

Karolina Isaksson, Hans Antonson and Linnea Eriksson, Layering and parallel policy making Complementary concepts for understanding implementation challenges related to sustainable mobility, TRANSPORT POLICY, 2017. 53, pp.50-57.

http://dx.doi.org/10.1016/j.tranpol.2016.08.014

Copyright: Elsevier

http://www.elsevier.com/

Postprint available at: Linköping University Electronic Press

http://urn.kb.se/resolve?urn=urn:nbn:se:liu:diva-134074

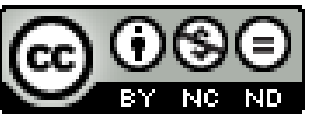




\title{
Layering and parallel policy making - complementary concepts for understanding implementation challenges related to sustainable mobility
}

\author{
Karolina Isaksson ${ }^{a b}$, Hans Antonson ${ }^{c d}$, Linnea Eriksson ${ }^{e}$
}

Published in: Transport Policy 53 (2017) 50-57

\section{Abstract}

This paper is focused on implementation challenges related to the integration of sustainable mobility in strategic local/regional land use and transport planning. The work was based on a case study of Stockholm, Sweden, focusing on four current plans and strategies of key importance for sustainable mobility. We identify and discuss implementation challenges related to sustainable mobility using a theoretical framework from the policy integration literature, with a focus on the dimensions of "layering", "drift" and "exhaustion" (Rayner \& Howlett 2009). The empirical analysis led us to identify a complementary dimension which we call 'Parallel policy making'. The parallel policy making reflects a fundamental lack of integration of sustainable mobility in policies and plans of strategic importance, which hinders effective policy integration. Altogether, we conclude that a better insight into the practice of parallel policy making is crucial for development of more effective implementation strategies for sustainable mobility in Stockholm and elsewhere.

\section{Introduction}

Sustainable mobility is a widely promoted ambition at various levels of governance from EU and national to the local policy arena. Within the EU, transport has been estimated to correspond to close to one quarter of all greenhouse gas (GHG) emissions (EC Climate Action, 2014). During the period 1990-2007 there was a general trend towards increased vehicle efficiency and cleaner fuels, but an overall increase in personal and freight transport means that GHG emissions from the transport sector are still increasing (ibid.). In the light of increased ambitions to keep global temperature rise to "well below two degrees" (UN 2015), the implementation of measures to reduce GHG emissions from transport is clearly one of the key strategic tasks for public authorities throughout the world.

In recent research literature, there has been a focus on urban and regional planning as a key arena for implementing sustainable mobility (e.g. Hull, 2008; Hickman et al., 2013; Hrelja et al., 2013; Pettersson, 2013). There is a rich body of knowledge about what constitutes sustainable mobility and about the types of policies and measures that need to be implemented in land use and transport planning to support such a development (see e.g. Banister, 2008; Newman and Kenworthy, 2015). In practice, however, sustainable mobility has proven difficult to implement, both because it involves so many spatial and administrative arenas and because

\footnotetext{
a VTI (Swedish National Road and Transport Research Institute), MAP Unit, Box 55685, SE-102 15 Stockholm, Sweden

${ }^{\mathrm{b}}$ Division of Urban and Regional Studies, Department of Urban Planning and Environment, KTH/Royal Institute of Technology, Stockholm, Sweden

c VTI (Swedish National Road and Transport Research Institute), MAP Unit, SE-581 95 Linköping, Sweden

${ }^{d}$ Lund University, Department of Human Geography, SE-223 62 Lund, Sweden

e Linköping University, Department of Thematic Studies, Division of Technology and Social Change, Linköping University, SE-58183 Linköping, Sweden
} 
it is a politically sensitive matter (Richardson et al., 2010; Geerlings et al., 2012; Hrelja et al., 2013). One of the main challenges in research on sustainable mobility is to build insights about key features for efficient implementation that rely on a thorough understanding of the often complex and messy institutional conditions that characterise planning and policy making in practice (cf. Steele, 2011).

The aim of this study was to generate insights on the implementation challenges involved when ambitions of sustainable mobility are introduced into strategic local/regional land use and transport planning arenas, and to discuss ways forward for more integrated strategies for sustainable transport and land use development. The work was based on a case study of Stockholm, Sweden. Stockholm has been internationally recognized for its ambitious agenda for sustainable mobility. In practice however, the city is facing challenges to implement its ambitions, for instance due to the general trends regarding land use and infrastructure development. In this paper, we will focus on four current plans and strategies of key importance for sustainable mobility in the city and the region. Three of the selected plans/strategies have been developed and agreed during the last 3-6 years, while the fourth has a much longer history, but has recently come to the fore during the same period as the others. Together, the selected plans/strategies provide a rich illustration of the work for sustainable mobility in Stockholm. By applying an analytical framework from the policy integration literature to these plans/strategies, the aim was to identify and discuss some of the key factors that explain implementation challenges in this context.

The paper is structured as follows: In the next section we present the framework used for analysis, which is based on existing knowledge of sustainable mobility and key concepts from the field of policy integration. This is followed by a methodology section where we describe how the study was carried out and then the case study, with analysis and clarification. The paper ends with a concluding discussion and suggestions for further research.

\section{Analytical framework}

\subsection{Sustainable mobility in theory and practice}

Since the late 1960s, there has been increasing awareness of the negative environmental impact of motorised transport and the high dependency on the private car (Tengström, 1990). Concepts such as 'sustainable transportation' and 'sustainable mobility' are responses to the wide range of negative effects related to the current transport system. These concepts are closely related and often used interchangeably. One definition of sustainable transportation, inspired by the Brundtland Commission, is "satisfying current transport and mobility needs without compromising the ability of future generations to meet these" (Black, 1996, p. 151). This means a transport system where environmental (e.g. fuel consumption, emissions, congestion) social (e.g. safety and equity) and economic accessibility can be sustained without causing harm to future generations of people (Richardson, 1999).

During the past two or three decades, researchers and policy makers have devoted great effort to developing policy measures that can help guide the current transport system in a more sustainable direction. Nykvist and Whitmarsh (2008) noted that such strategies typically comprise improving the efficiency and reducing the impact of vehicles; pushing for more sustainable modes of travel; and implementing initiatives to reduce the need to travel. This resonates well with the work of Banister (2008), according to whom sustainable mobility requires a shift away from a traditional transport policy paradigm that has made cars the 
dominant mode of travel. Banister emphasises the need for a new transport and land use planning paradigm, which includes modal shift, a reduced need to travel (less trips), reduced trip length and altogether greater efficiency in the transport system (Banister, 2008, p. 75). Banister also stresses the need to distinguish between accessibility and mobility (and prioritise the former), to work strategically with visions and scenarios instead of forecasts and, consequently, to prioritise sustainable transport modes such as walking, cycling and public transport instead of motorised transport (ibid.). Together with several others, he underlines the importance of creating built environments with sufficient density to make public transport and other sustainable modes of travel attractive and functional (Banister, 2008; Curtis et al., 2009; Newman and Kenworthy, 2015).

Table 1 summarises key elements of the "sustainable mobility paradigm" presented by Banister (2008). It clarifies the difference between that approach and the conventional transport planning paradigm, which is based on forecasting (predict and provide), focuses on traffic (especially private car), builds on traditional economic evaluation and views travel primarily as a derived demand. 
Table 1. Contrasting approaches to transport planning (Banister, 2008, p. 75)

\begin{tabular}{|c|c|}
\hline $\begin{array}{l}\text { The conventional approach - transport } \\
\text { planning and engineering }\end{array}$ & An alternative approach - sustainable mobility \\
\hline Physical dimensions & Social dimensions \\
\hline Mobility & Accessibility \\
\hline Traffic focus, particularly on the car & $\begin{array}{l}\text { People focus, either in (or on) a vehicle or on } \\
\text { foot }\end{array}$ \\
\hline Large in scale & Local in scale \\
\hline Street as a road & Street as a space \\
\hline Motorised transport & $\begin{array}{l}\text { All modes of transport, often in a hierarchy with } \\
\text { pedestrians and cyclists at the top and car users } \\
\text { at the bottom }\end{array}$ \\
\hline Forecasting traffic & Visioning on cities \\
\hline Modelling approaches & Scenario development and modelling \\
\hline Economic evaluation & $\begin{array}{l}\text { Multicriteria analysis to take account of } \\
\text { environmental and social concerns }\end{array}$ \\
\hline Travel as a derived demand & $\begin{array}{l}\text { Travel as a valued activity as well as a derived } \\
\text { demand }\end{array}$ \\
\hline Demand-based & Management-based \\
\hline Speeding up traffic & Slowing movement down \\
\hline Travel time minimisation & $\begin{array}{l}\text { Reasonable travel times and travel time } \\
\text { reliability }\end{array}$ \\
\hline Segregation of people and traffic & Integration of people and traffic \\
\hline
\end{tabular}

Overall, there is a wide knowledge on sustainable mobility and the types of changes it requires. In practice, however, there are a number of difficulties related to its implementation. Some of the challenges that have been discussed in current research relate to common implementation problems such as lack of clear policy goals and pathways (Hickman et al., 2013) and/or a lack of funding for measures/investments required to support a transition to sustainable mobility (Pettersson, 2014). Other difficulties include a remaining dissonance about the policy ambition as such, both within and between different administration/implementation levels (Hrelja et al., 2012; Finnveden and Åkerman, 2014; Pettersson, 2014; Antonson et al., 2016). Multiple studies have emphasised the importance of gaining a better insight into the institutional conditions (norms, frameworks, discourses, professional cultures and networks, power relations etc.) that shape regional and local policy and planning processes (Hull, 2008; Richardson et al., 2010; 
Antonson, 2011; Hickman et al., 2011; Hrelja et al., 2013; Isaksson and Storbjörk, 2012; Pettersson, 2013; Olsson et al., 2015). In the present study, the distinction between conventional transport planning, on the one hand, and sustainable mobility, on the other, is a key dimension of the content analysis of the selected plans/strategies.

\subsection{How can challenges to policy integration be understood?}

The present analysis applies a broad understanding of policy as a course of action or inaction aiming at a certain outcome (Heclo, 1972) and thus as something that is normally performed through 'a set of interrelated decisions [....] concerning the selection of goals and the means of achieving them within a specified situation [...]' (Jenkins, 1978, p. 15).

A large number of empirical studies on policy making and implementation in the past two or three decades have demonstrated that policy making should be seen as a complex activity, far from the rational models that once influenced policy analysis. In practice, policies and policy making are matters of continuous redevelopment, negotiation and bargaining and the conditions for implementation in terms of, for instance, problem framings and actors involved vary throughout the process (Pressman and Wildavsky, 1973; Barrett and Fudge, 1981; JenkinsSmith and Sabatier, 1994;). Hence, as stated by Rayner and Howlett (2009, p. 99), policy formation and implementation must be regarded as 'always embedded in pre-existing contexts where the relics of earlier policy initiatives are found in paradigms, institutions, practices and established actor networks.'

The literature on policy integration refers to situations where 'new' policy objectives, goals and ambitions are to be incorporated or mainstreamed into existing policy arenas, i.e. situations in which cross-cutting issues 'transcend the boundaries of established policy fields' (Stead and Meijers, 2009). The literature explores the complexities and challenges that this might create in terms of goal conflicts, policy contradictions etc. and discusses key conditions for enhanced efficiency and long-term change, which is essentially what policy integration is about (Storbjörk and Isaksson, 2013).

The issue examined in this study, namely implementation of sustainable mobility into land use and transport planning, is a typical example of policy integration. In the literature, Rayner and Howlett (2009) discuss the challenges involved when new policy ambitions are to be implemented in pre-existing contexts. In their understanding, policy arrangements tend to be complex products of many years of working and, since they have evolved over many years, they normally contain a mix of aims and instruments. Based on this, Rayner and Howlett use the analytical concept of 'policy layering', which refers to situations where different policy goals, instruments and programmes are stacked on top of each other (Thelen, 2003; Hacker, 2005; Rayner and Howlett, 2009). Rayner and Howlett describe layering as a common phenomenon and as a natural consequence of how policy processes work. Over time, however, multiple layering leads to policy arrangements which are inefficient, complex and costly to administer. This, in turn, often motivates the development of new integrated strategies, but these always risk embodying new ineffective instrument mixes or incomplete policy reform efforts that lead to poor outcomes (Rayner and Howlett, 2009).

A key contribution of the work by Rayner and Howlett is the development of a fine-grained approach to support the analysis of challenges and inefficiencies of integrated policy ambitions. Their framework, which is based on earlier works within policy literature, comprises five 
dimensions, namely: 'drift', 'conversion', 'layering', 'displacement' and 'exhaustion' (Rayner and Howlett, 2009), which are defined as follows:

Layering:

A process whereby new goals are simply added to existing goals which leads to situations of incoherence and inconsistencies.

Drift:

A situation where the goals of a policy change but the instruments used to implement them remain the same - which makes the tools inconsistent and inefficient in relation to the policy.

Conversion: $\quad$ A situation where the instruments change but the policy goals remain the same as before - which means a mismatch between the means and ends of the policy.

Displacement:

A process of rediscovering alternative logics and possibilities within an existing policy.

Exhaustion:

When a policy or policy regime starts to undermine itself, thus paving the way for a more radical shift.

The analytical framework presented by Rayner and Howlett was used to inform the present analysis of four plans/strategies for Stockholm, in an exploration of challenges and complexities related to the implementation of sustainable mobility.

In concrete terms, the following research questions guided the present analysis:

1) How are the four plans/strategies explicitly framed and justified in terms of sustainable mobility (compared with a more conventional transport planning paradigm)?

2) What are the most apparent inconsistencies and other challenges within and/or between the four plans/strategies in this respect?

3) Based on the findings from research questions 1 and 2, what conclusions can be drawn about how to support more efficient implementation of sustainable mobility in the local land use and transport planning arena?

\section{Methodological considerations}

Empirically, the present analysis is based on a case study of Stockholm, Sweden. According to Flyvbjerg (2006), single case studies can serve as a sound basis for drawing more general conclusions, provided that the case in question is rich and illustrative. We understand Stockholm as a particularly interesting case due to its wide recognition as a city with ambitious policies for sustainable mobility, encompassing a high share of public transport, congestion taxation etc (Little and UITP, 2014). Stockholm has a long tradition of being less car-dependent than other cities with similar levels of economic affluence and car-ownership (Cameron et al 2004). Previous studies have highlighted the importance of long-term strategies for land use and public transport integration that influenced the development of the city and the region in 
earlier decades (ibid.). Today however, the situation seems less clear. Developments during the last decade show, on the one hand, a remaining high share of public transport, which remains the most common transport mode along the radial routes into the city centre. The average numbers for car-ownership in the city have decreased since 2008 and the number of cyclists is growing. On the other hand, car traffic has increased in the less central parts of the city and the region, where the largest population growth occurs, and is expected to grow even further in the future (City of Stockholm 2016). New investments in road infrastructure is expected to support this development even further. At a general policy level, there is a remaining emphasis on the need to promote sustainable mobility, but the actual developments in the region as a whole appears to be at a critical stage.

Altogether, we see Stockholm as a 'critical case' (Flyvbjerg, 2006, p. 229) for exploring implementation barriers to sustainable mobility. The paradoxes, conflicts and challenges that arise in this 'favourable' policy context (the long tradition planning for sustainable travel, the remaining high ambitions related to sustainable mobility and with competent planning organisations and available resources etc.) are likely to arise in other contexts, too. In other words, the case of Stockholm can be understood as being of strategic importance in relation to the more general problem of implementing plans and strategies that support sustainable mobility (Flyvbjerg, 2006).

To explore the current policy for sustainable mobility in Stockholm, we opted to focus on four main plans/strategies of key relevance for sustainable mobility. These initiatives differ in their overall framing, specific aims and level of realisation, but are all strategic initiatives that will be highly influential for mobility patterns in the city and the region for many years ahead. The selected initiatives are:

1) The regional development strategy for Stockholm (approved by Stockholm County Council 2010).

2) The comprehensive city plan for Stockholm (approved by Stockholm City Council in 2010).

3) The urban mobility strategy for Stockholm, 2012 (approved by Stockholm City Council in 2013).

4) The Stockholm Bypass (a large road project that has been planned for decades. The latest round of planning was carried out 2005-2011. The bypass is currently under construction).

These initiatives reflect the complex governance setting that characterises this policy arena in practice. Together, the initiatives involve actors at different governance levels (see Figure 2). The regional development strategy (1) was developed by Stockholm County Council, while both the comprehensive city plan (2) and the urban mobility strategy (3) were developed by the City of Stockholm. However, there are links between these processes and they are intended explicitly - to support and reinforce each other.

To get a more complete picture of the current local/regional land use and transport planning context in Stockholm, there is a need to include documents about the Stockholm Bypass (4), which is a large investment in new transport infrastructure. As a single infrastructure project, the Bypass is a somewhat different type of example from the regional plan, city plan and additional mobility strategy. However, due to its size and its influence on the other plans, it must be mentioned in any analysis of current land use and transport planning in Stockholm. The Stockholm Bypass is also a different type of process from the other three, which are assigned to specific institutions. Politically, it was initiated by a broad set of actors and 
institutions at regional and local level and it is dependent on state funding (including congestion tax revenues). Therefore, in practice it has been planned and designed by the Stockholm division of the Swedish Transport Administration (STA, formerly the Swedish Road Administration, SRA). A specific strength with selection of these four plans/strategies for the present analysis is that they represent and manifest not only the rhetorical dimensions of sustainable mobility, but contain also concrete priorities and investments.

The empirical material used for the analysis consisted of the formal documents about the four plans/strategies. For the regional development plan, the city comprehensive plan and the urban mobility strategy (1-3), there was one obvious main document per each plan/strategy. In the case of the Stockholm Bypass, however, the situation is more complex, since this is a project with a longer history and a wider constellation of actors involved. Four key documents on the Stockholm Bypass produced by the SRA were selected for the analysis: i) the feasibility study (FS), ii) the associated Environmental Impact Assessment report (EIS), iii) a written statement to the Swedish government presenting the results of the FS together with a summary of stakeholder opinions, in order to get a permit to proceed to the next planning phase, and iv) a written report from the Stockholm Negotiation, which was appointed by the government to conduct a hearing on Stockholm County infrastructure in order to ensure prompt implementation of Metro expansion, increased housing development and various forms of cofinancing from the municipal authorities involved.

The present analytical work consisted of discursively orientated (Gee and Hanford, 2012) qualitative content analysis of these documents (Merriam, 2009). This involved reading the key document(s) for each plan/strategy carefully and systematically. Specific attention was paid to the framing and the overall objectives, and the way in which they were operationalised (or planned to be operationalised) in concrete instruments and measures. Throughout the analysis, the distinction made by Banister (2008) between a conventional approach to transport planning and a sustainable mobility approach was applied (as summarised in Table 1) as a basic framework for the content analysis. The degree to which sustainable mobility proved to be implemented in each of the four plans/strategies was then analysed with the support of the framework developed by Rayner and Howlett (2009). In this analysis, specific attention was paid to goals and objectives stated in the documents. The main attention here was directed to explicit statements, but implicit assumptions which could be identified as an underlying rationale of a certain text or line of argument etc. were also scrutinised.

\section{Empirical analysis}

\subsection{The regional development plan for the Stockholm region}

The regional development plan for the Stockholm region outlines the future land use and economic development for Stockholm County. It is intended to act as a strategic document to realise the vision of becoming Europe's most attractive metropolitan region. Within its strategy for realisation of this overall vision, the region has identified four goals: i) to become an open and accessible region, ii) to become a leading growth region by 2030, iii) to become a region with a good living environment by 2030 and iv) to become a resource-efficient region by 2030 .

In order to achieve the vision and fulfil these goals, the region has formulated six strategies, the first of which is to increase sustainable capacity and quality within education, transport and the housing sector (SCC, 2010, p. 22). As part of this, the plan mentions the need to develop "Resource-efficient solutions for accommodation and transport" (ibid., p. 6). Another strategy is to develop “a dense, polycentric region” (ibid., p. 23). This strategy is closely connected to 
suggestions for improved new investments in both public transport and road infrastructure, which are intended to make inter-regional transport smoother and thereby include a larger area in the regional labour market (ibid., p. 141).

The plan sets out key strategies for land use development and the management of environmental, economic and social dimensions of sustainability in the context of polycentric development. The plan relates to the idea of sustainable mobility, for instance by stressing the need to develop a transport system with limited negative consequences on the environment and health and cites various measures to promote a modal shift - for instance by supporting the development of "a public transport system, both on land and at sea, that is attractive and accessible to all. It has to be developed to cope with the large flows of travellers and to win market share from the car, in order to reduce congestion on the roads and to meet the climate requirements.” (SCC, 2010, p. 55).

Measures to stimulate more cycling and walking are also highlighted as important. The plan stresses increased density, in order to improve the conditions for walking, cycling and public transport and reduce the dependency on private cars. The list of concrete measures identified as crucial to meet future needs includes the "Transfer of car journeys to public transport, walking and cycling" (SCC, 2010, p. 84). There is emphasis on the potential to work with a combination of sticks (economic measures) and carrots (improved public transport) and evaluate the potential in terms of the environment and health. One of the economic measures mentioned is a congestion tax, with the recommendation that it be complemented by a kilometre tax (ibid., p. 56).

Thus, the need for a modal shift emerges clearly in the document. At the same time, however, car dependency is not questioned or challenged explicitly. The plan stresses the importance of the congestion tax and the possibility to restrict car use in the city centre, but it also sets out the need to substantially increase capacity on the road network and supports the plans for further extension of the road network. The existing road infrastructure is characterised as "insufficient" and it is stated that it "impairs the links between the northern and southern parts of the county." (SCC, 2010, p. 56). Here, the document refers to an anticipated further increase in population which "means that transport requirements will increase, which means that relief road traffic routes will also need to be built." (ibid., p. 56). Looking more closely at the details, it is clear that the enhanced road capacity will consist both of smaller complementary roads but also two large new motorways: Stockholm Bypass and, later on, a new easterly connection that will complete the full ring road around the city (ibid., p. 141). The plan thereby reflects the remaining traits of a clearly conventional transport planning paradigm with the focus on car traffic and the 'predict-and-provide' rationale. According to the plan, remaining problems with car traffic should be solved by technological innovations, for example by increasing the use of biofuels and plug-in vehicles in the region, new silent pavements and/or a ban on studded tyres. The importance of education and information in making individuals change their transport choices to less private car use is also stressed.

Overall, there are obvious incoherencies in the regional development plan for Stockholm in its approach to sustainable mobility. As noted above, enhanced resource efficiency is one of the key objectives of the plan, and it is stated that the transport system is "without doubt the most difficult regional challenge from a resource-efficiency perspective.” (SCC, 2010, p. 204) Throughout the plan, there are several statements that emphasise the need to offer good alternatives to the car and to increase the market share of public transport. At the same time, the plan supports continued expansion of the road network - even though it is explicitly stated 
that this will actually lead to increased road traffic. Altogether, the simultaneous support for both new road infrastructure and public transport, cycling and walking makes the plan essentially unclear in relation to sustainable mobility. From the perspective of Rayner and Howlett (2009), the content of the regional development plan can be understood as a matter of both layering and drift. As regards layering, sustainability emerges strongly in the overall goals but closer scrutiny of the content of the plan reveals other rationalities that exist alongside the sustainability ambition. For instance, a key strategy for further economic growth is to expand the labour market by regional enlargement. The potential existence of goal conflicts between this goal (and strategies to reach it) and the goals of resource efficiency and a good living environment is never discussed in the plan.

Elements of drift are evident if we look at the concrete measures being set out in the plan. Some of these are typical for a 'sustainable mobility' approach, such as the congestion pricing instrument, and the proposed support for more public transport, biking and walking. However, the intention to construct two large new motorways makes the overall content of the regional development plan inconsistent and will probably to reduce the efficiency of the other measures.

\subsection{The city plan}

The city plan, adopted in April 2010, is a long-term comprehensive water and land use plan for the city of Stockholm. The plan, which is named The Walkable City, presents several policy initiatives intended to increase the city's attractiveness, promote economic development and at the same time decrease the impact on the local and global environment. It also aims to provide guidance regarding the city's intentions and objectives for sustainable development. It refers explicitly to the climate challenges, stating that "it will take considerable effort /.../ to achieve the ambitious target of a fossil fuel free city by 2050.” (City of Stockholm, 2010, p. 10).

Sustainable mobility is a key issue in the plan. It is noted that "one of the single greatest challenges for the region and for the City Plan is to increase access to the transport system while at the same time minimising the environmental impact of the transport sector" (City of Stockholm, 2010). To succeed with this, the plan points out the importance of continuous achievements in environmental technology, alternative fuels, developing a densely built environment that supports major expansion of public transport, walking and cycling, and limiting use of the car (ibid., p. 10, 22). Furthermore, the plan mentions the potential to use existing infrastructure more efficiently and to use financial instruments or by other means support more sustainable travel patterns - through congestion taxation and/or parking policies. Public transport is referred to as "the heart of the future transport system" and "by far the most efficient way of moving people around" (City of Stockholm, 2010, p. 22), and the plan states that a greater modal split will be needed if the goal of sustainable travel is to be achieved. In addition, it notes that the ability to combine different transport modes, such as bicycles and public transport, also needs to be facilitated.

Stockholm is a small city in a global perspective, so in order for it to compete with other European cities, enlargement of the regional labour market is emphasised in the city plan (City of Stockholm, 2010). The transport system is considered vital in relation to this ambition. The plan also stresses the need for a holistic perspective on the transport system, in order to enable efficient coordination of different policy sectors and of traffic and housing planning. In doing so, it refers explicitly to a range of already agreed road and railway infrastructure projects. Two railway infrastructure projects currently being built (Citybanan, Mälarbanan) are mentioned as the most important public transport projects to enhance the connection between north and south 
in the region. The city plan refers explicitly to the plans to construct the Stockholm Bypass, a new motorway project intended to fulfil the same purpose, and also mentions the easterly connection as another important project for the future City of Stockholm (ibid., p. 76f). The city plan acknowledges the problem that "an increase in road capacity contributes to new car journeys that previously would have been made by other means, if at all” (ibid., p. 22). However, this statement does not alter the city plan's support for the new road investments.

Altogether, the city plan is characterised by a complexity which is similar to the one identified in the regional development plan. The city plan expresses ideas of sustainable mobility, while at the same time encompassing elements of a conventional transport planning approach. If it had not been for the explicit support for construction of new motorway infrastructure, it would have been close to a cohesive strategy for sustainable mobility. As it stands, however, it is one more example of layering and drift and altogether it does not provide full support for the idea of sustainable mobility.

\subsection{The urban mobility strategy}

The urban mobility strategy sets out the guiding policies on how to use the streets and roads in Stockholm City if the goals of an efficient, safe, attractive, environmentally friendly and healthy Stockholm are to be realised. The urban mobility strategy was approved by Stockholm City Council in early 2013. It is clearly related to other strategic documents, such as the city plan, but has a more operational focus. It is framed around the notion of a growing city, where the transport system is a key structure to enable the creation of a sustainable and livable urban environment. The mobility strategy sets out clearly that a growing population means challenges for the city's streets, roads and railways, and that there is a need to "promote the development of those means of transport that are most efficient in terms of usage of space and transportation." (City of Stockholm, 2012, p. 3).

The urban mobility strategy is clearly related to the notion of sustainable mobility through its focus on space-efficient transport. It acknowledges the need for the city's roads and streets to "provide space for a variety of functions of interests" (City of Stockholm, 2012, p. 4) and, in contrast to the regional development plan and the city plan, it talks explicitly about the need to prioritise whether there will be enough room for all (ibid., p. 5). Furthermore, it states that:

"the proportion of journeys undertaken by car must be reduced and more people need to choose to walk, cycle and use public transport. To achieve this, the street environment must make the step-by-step transition to more dedicated lanes for public transport, more cycle lanes, fewer parking places and an enhanced street environment for pedestrians.” (ibid., p. 6).

The urban mobility strategy also mentions the need for mobility management to support a change in travel patterns towards high-capacity and energy-efficient modes of transport. The overall idea of clear priorities between different modes of traffic is illustrated in Figure 1. 


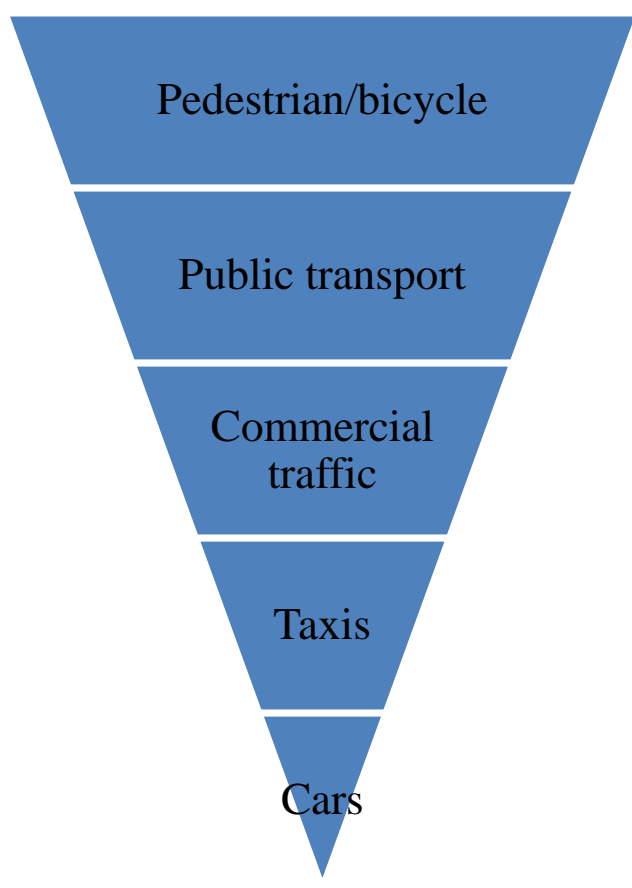

Figure 1. Priority of transport modes to achieve sustainable mobility in Stockholm, adjusted from the Stockholm Urban Mobility Strategy (2012).

The content of the urban mobility strategy is clearly inspired by ideas of sustainable mobility. It can be viewed as an example of displacement and even exhaustion of the conventional transport planning paradigm. The document is based on the goals in the city plan, but contains a much clearer and less ambiguous strategy for realising the idea of a walkable city and contains straightforward formulations about the need to reduce car use and increase the share of walking, cycling and public transport.

However, alongside this clear approach, the urban mobility strategy still contains elements of the conventional approach to transport planning. As a strategy, it is explicitly linked to the city plan, and thus it also supports the expansion of the motorway network. This creates a fundamental ambiguity in the document. On the one hand, it stresses the importance of urban planning to reduce the need to travel and of traffic planning to optimise the use of existing infrastructure. On the other hand, it refers to the need for 'a road network that leads away major traffic flows' (ibid., p. 9). Since the document is so well-developed, explicit and coherent about sustainable mobility in all its other parts, it does not seem appropriate to explain this as a matter of mere layering or drift, which are concepts that fit best to a situation when new ideas emerge and take some time before they are fully implemented. Instead, the situation represents a fundamental and still unsolved conflict between two diverging and incompatible transport planning paradigms. Instead of a completed exhaustion of the conventional approach to transport planning, the two rationales now exist in parallel to each other - thus making the longterm strategy for transport planning in Stockholm fundamentally unclear.

\subsection{The Stockholm Bypass}

The Stockholm Bypass was agreed through a separate negotiation process (The Stockholm Negotiation (Stockholmsförhandlingen)) between the state, the region (through Stockholm County Council) and the City of Stockholm, together with other municipalities in the region. 
The negotiation was finalised and presented to the public in 2007 and included, among other things, the construction of a new railway tunnel and investments in new road infrastructure, the main project being the Stockholm Bypass (Stockholmsförhandlingen, 2007). The Stockholm Bypass is a $21 \mathrm{~km}$ long road (three lanes in each direction) that will connect the northern and southern parts of the city and the region. An $18 \mathrm{~km}$ stretch of the road will run within a tunnel. The key motive behind the project is "to meet future transportation needs and to tie the region together" (SRA, 2005, p. 16) and also, as stated in the Stockholm Negotiation, to reduce traffic and congestion in the inner city (Stockholmsförhandlingen, 2007). The Stockholm Bypass has a long history. The project has been discussed for several decades and was almost implemented at least twice before, in the 1970s and 1990s (Isaksson, 2001). However, on both previous occasions the project was abandoned due to its expected environmental consequences and problems with funding (ibid.). The project was declared dead in 1997, but only four years later, in 2001, the SRA initiated a new initial study and concluded that there was a need to increase the road capacity between northern and southern parts of the Stockholm region (SRA, 2001).

The process continued with a feasibility study (FS) that was completed in 2005 and investigated three alternative solutions: the Stockholm Bypass, the Ulvsunda Diagonal (a more central road tunnel) and a 'Combination' alternative, consisting of large public transport investments in combination with a congestion tax and some new road investments (SRA, 2005). The FS singled out the Stockholm Bypass as the best alternative, partly because it was considered the best option for developing "an attractive and sustainable region" (SRA, 2008, p. 11) and partly due to its potential to "develop a sustainable and robust road transport system for cars and goods transport" (ibid., p. 23). Thus, the project was not proposed on the grounds of sustainability and was clearly not about reducing traffic or supporting a modal shift. Instead, the project represented a highly conventional approach to transport planning, with the idea of 'predict and provide' being central. In the planning documents there is a recurring focus on the car as the primary mode of transport. Sustainability is intended to be achieved through shorter vehicle trips (the Stockholm Bypass creates a short-cut for motor traffic), reduced congestion (no fuel losses and less $\mathrm{CO}_{2}$ emissions) and reduced vehicle noise for residents in central areas (SRA, 2008, p. 82). There is an absence of reasoning in the documents about the potential to improve accessibility by a modal shift and about the potential to reduce the transport requirements in general. Moreover, there is no discussion of new roads leading to new problems such as induced traffic and negative consequences for public transport, walking and biking.

From the perspective of Rayner and Howlett (2009), it can be concluded that the Stockholm Bypass is closely related to the types of goals and ambitions that cause elements of layering and drift in the regional development plan and the city plan. Through its focus on increased road capacity and motorised transport (particularly by car), it represents a conventional traffic planning approach, far from the ideas of sustainable mobility. It is also interesting to reflect upon its status as a non-questionable project. Being part of a broad political agreement (reached in separate negotiations in parallel to the regular policy and planning arena), it has pivotal status and has remained unchallenged even though new goals and ambitions have been established for the long-term development of the city and the region. There is no concept in the Rayner-Howlett framework that fits with this situation. The present analysis of the Stockholm Bypass project found no indication at all that a policy integration process is underway. The situation should not be understood in terms of layering, since it is not primarily a matter of different goals being added on to each other. Rather, what is apparent is a strong rationale of conventional transport planning that exists in parallel to the idea of sustainable mobility. In practice, this type of new infrastructure will support increased car use and urban sprawl and thus it will effectively work as a barrier to implementation of sustainable mobility. 


\section{Concluding discussion}

This analysis of the four types of plans/strategies produced for the City of Stockholm illustrates some of the implementation challenges that may arise when goals and ambitions related to sustainable mobility are to be implemented in local and regional land use and transport planning. Sustainable mobility is partly integrated in several of the plans/strategies that are intended to steer the long term land use and transport developments in Stockholm, but the picture is complex. In the analysis of the four plans/strategies, we have found several contradictory elements. Based on the framework developed by Rayner and Howlett (2009), we have seen that both the city plan and the regional development plan contain elements of layering and drift, which means that ideas of sustainable mobility exist side by side with a more conventional approach to transport and land use development. Overall, the idea of sustainable mobility has progressed farthest in the urban mobility strategy for Stockholm, in which there are clear signs of an ongoing exhaustion of the conventional approach to transport planning. The reason for this is probably a progression over time, as the last few years have been a period of significant political change in issues relating to traffic and mobility in the city of Stockholm (Richardson et al., 2010). Considering that this strategy was produced a few years later than the other strategies/plans studied, it can be seen as an indication that the idea of sustainable mobility has become more firmly rooted within the city council over time.

If the present analysis of policy for sustainable mobility in Stockholm had only encompassed the regional development plan, the city plan and the urban mobility strategy, we would probably have concluded that Stockholm is a city on a slow but steady course toward sustainable mobility. we would probably also have interpreted the dimensions of layering and drift as natural distractions in the process of policy integration. However, considering also the nonquestionable Bypass Stockholm, alongside a remaining support also for other large investments in new road infrastructure, we came to the conclusion that sustainable mobility is still far from being integrated in the Stockholm land use and transport planning arena. Instead of seeing the dimensions of layering and drift in the city plan and the regional development plan as promising signs of an ongoing stepwise integration of sustainable mobility, we see them as signs of a confusing practice of parallel policy making that reflect a fundamental lack of integration of sustainable mobility in arenas and in projects that really matter.

Altogether, the implementation challenges identified in this case are far from the idea of stepwise progression that is assumed in the framework by Rayner and Howlett (2009). Rayner and Howlett are clear that policy integration is a complex process that normally includes complexity and contradiction, but what we found in this case is better described as an unresolved conflict between two incompatible planning paradigms. We claim this to be a main reason behind current difficulties related to the integration of sustainable mobility in Stockholm. This challenge is also a key issue that needs to be handled if the process of policy integration shall proceed. Based on these findings, we suggest that the model of policy integration developed by Rayner and Howlett (2009) should be complemented with a dimension that addresses situations where explicitly stated goals/ambitions point in one direction, whereas practice has a content that is completely incompatible with the outspoken policy direction. We formulated the concept of 'parallel policymaking' as a way to refer to this type of challenge for policy integration. We would welcome input from other researchers on this proposed concept, e.g. reporting whether there are more examples of parallel policy making around the world and how better insights into parallel policymaking could support the development of more effective implementation strategies in the future. 


\section{Acknowledgements}

The authors wish to thank the researchers in the FAST-network at Linköping University and the Swedish National Road and Transport Research Institute (VTI) for valuable comments on an earlier version of this manuscript. We also want to thank the two anonymous reviewers whose careful readings contributed substantially to our work to improve the paper. Thanks also to Mary McAfee for proof reading the manuscript. The work was financially supported by FORMAS 250-2010-1594 and the Swedish Energy Agency.

\section{References}

Antonson, H. (2011) 'The Treatment of Landscape in a Swedish EIA Process', Environmental Impact Assessment Review, 31(3), pp. 195-205.

Antonson, H., Storbjörk, S., Hjerpe, M., Isaksson, K. (2016) 'Negotiating climate change responses: Regional and local perspectives on transport and coastal zone planning in South Sweden', Land Use Policy, 52, pp. 297-305.

Banister, D. (2008) ‘The sustainable mobility paradigm’, Transport Policy, 15(2), pp. 73-80.

Barrett, S., Fudge, C. (ed.) (1981) Policy and action: essays on the implementation of public policy, Methuen, London.

Black, W.R. (1996) 'Sustainable transportation: a US perspective', Journal of Transport Geography, 4, 151-159.

Cameron, I. Lyons, T.J. Kenworthy, J. R. (2004) 'Trends in vehicle kilometres of travel in world cities, 1960-1990: underlying drivers and policy responses’ Transport Policy, 11, pp. 287-298.

City of Stockholm (2010) The Walkable City, Stockholm City Plan. Adopted by Stockholm City Council on 15 March 2010. The City of Stockholm 2011:1.

City of Stockholm. 2012. Urban Mobility Strategy, The City of Stockholm: Traffic Administration.

City of Stockholm (2016) Trafikbarometern, http://miljobarometern.stockholm.se/trafik/ (Accessed 2014-07-23). (in Swedish)

Curtis, C., Renne, J. L., Bertolini, L. (2009) Transit Oriented Development. Making it Happen, Farnham, Surrey, England: Ashgate.

European Commission (EC). (2014) Climate action 2014: Reducing emissions from transport, http://ec.europa.eu/clima/policies/transport/index_en.htm (Accessed 2014-03-14).

Finnveden, G., Åkerman, J. (2014) 'Not planning a sustainable transport system', Environmental Impact Assessment Review, 46, pp. 53-57. 
Flyvbjerg B. (2006) 'Five misunderstandings about case-study research', Qualitative Inquiry, 12(2), pp. 219-245.

Gee, J.P., Handford, M. (eds.) (2012) The Routledge handbook of discourse analysis. London: Routledge.

Geerlings, H., Shiftan, Y., Stead, D. (eds.) (2012) Transition towards sustainable mobility: the role of instruments, individuals and institutions, Farnham: Ashgate

Hajer M and Versteeg W. (2005) 'A Decade of Discourse Analysis of Environmental Politics: Achievements, Challenges, Perspectives’, Journal of Environmental Policy \& Planning, 7(3); pp. $175-184$.

Heclo, H. H. (1972). 'Policy Analysis', British Journal of Political Science, 2(1), 83-108.

Hedegaard Sørensen, C., Isaksson, K., Macmillen, J., Åkerman, J. \& Kressler, F. (2014) 'Strategies to manage barriers in policy formation and implementation of road pricing packages', Transportation Research Part A, 60, pp. 40-52.

Hickman, R., Hall, P., Banister, D. (2013) ‘Planning more for sustainable mobility’, Journal of Transport Geography, 33, pp. 210-219.

Hickman, R., Ashiru, O., Banister, D. (2011) ,Transitions to low carbon transport futures: strategic conversations from London and Delhi', Journal of Transport Geography, 19, pp. 1553-1562.

Hrelja, R., Isaksson, K., Richardson, T. (2012) 'IKEA and small city development in Sweden: Planning myths, realities, and unsustainable mobilities', International Planning Studies, 17(2), pp. 125-145.

Hrelja, R., Isaksson, K., Richardson, T. (2013) 'Choosing conflict on the road to sustainable mobility: A risky strategy for breaking path dependency in urban policy making', Transportation Research Part A, 49, pp. 195-205.

Hull, A. (2008) 'Policy integration. What will it take to achieve more sustainable transport solutions in cities?', Transport Policy, 15(2), pp. 94-103.

Isaksson, K., Richardson, T. (2009) 'Building legitimacy for risky policies: the cost of avoiding conflict in Stockholm’, Transportation Research A, 43(3), pp.251-257.

Isaksson, K., Storbjörk, S. (2012) 'Strategy making and power in environmental assessments. Lessons from the establishment of an out-of-town shopping centre in Västerås, Sweden', Environmental Impact Assessment Review, 34, pp. 65-73.

Jenkins, W.I. (1978). Policy analysis: a political and organisational perspective. Martin Robertson, London.

Jenkins-Smith, H. C. and Sabatier, P. A., (1994) 'Evaluating the Advocacy Coalition Framework', Journal of Public Policy, 14(2), pp. 175-203. 
Little, A.D., UITP. (2014) The Future of Urban Mobility 2.0. Imperatives to shape extended mobility ecosystems of tomorrow.

Merriam, S.B. (2009) Qualitative research: a guide to design and implementation. (2. ed.), Jossey-Bass, San Francisco.

Newman, P., Kenworthy, J. (2015) The end of automobile dependence. How Cities are Moving Beyond Car-Based Planning, Island Press, USA.

Nilsson, M., Eckerberg, K. (eds.) (2007) Environmental Policy Integration in Practice. Shaping Institutions for Learning. London: Earthscan.

Nykvist, B., Whitmarsh, L. (2008) A multi-level analysis of sustainable mobility transitions: Niche development in the UK and Sweden. Technological Forecasting and Social Change, 75(9), pp. 1373-1387.

Olsson, L., Hjalmarsson, L., Wikström, M., Larsson, M. (2015) 'Bridging the implementation gap: Combining backcasting and policy analysis to study renewable energy in urban road transport', Transport Policy 37, pp. 72-82.

Persson, A. (2007) 'Different Perspectives on EPI’ in: Nilsson, M., Eckerberg, K. (eds.), Environmental Policy Integration in Practice; Shaping Institutions for Learning, pp. 24-48. Earthscan, London.

Pettersson, F. (2013) 'From words to action: Concepts, framings of problems and knowledge production practices in regional transport infrastructure planning in Sweden', Transport Policy, 29, pp. 21-22.

Pettersson, F. (2014) Swedish Infrastructure Policy and Planning: Conditions for Sustainability. (Diss.) Lund University, Lund.

Pressman, J. L., Wildavsky, A. B. (1973) Implementation: how great expectations in Washington are dashed in Oakland; or, why it's amazing that federal programs work at all: this beeing a saga of the Economic development administration as told by two sympathetic observers who seek to build morals on a foundation of ruined hopes. University of California Press, Berkeley.

Rayner, J., Howlett, M. (2009) 'Introduction: Understanding integrated policy strategies and their evolution', Policy and Society, 28(2), pp.99-109.

Richardson, B.C. (1999) 'Toward a policy on a sustainable transportation system', Transportation Research Record, Journal of the Transportation Research Board, 1670, pp. 27-34.

Richardson, T., Isaksson, K., Gullberg, A. (2010) 'Changing frames of mobility through radical policy interventions? The Stockholm congestion tax', International Planning Studies, 15(1), pp.53-67.

Skårfors, R. (2001) Stockholms trafikledsutbyggnad: förändrade förutsättningar för beslut och implementering 1960-1975. Uppsala University, Uppsala.Staed, D., Meijers, E. (2009) 
'Spatial Planning and Policy Integration: Concepts, Facilitators and Inhibitors', Planning Theory \& Practice, 0(3), pp. 317-332.

Steele, W. (2011) 'Strategy-making for Sustainability: An Institutional Learning Approach to Transformative Planning Practice', Planning Theory \& Practice, 12(2), pp.205-221.

Storbjörk, S. and Isaksson, K.: ‘ 'Learning is our Achilles heel’ Conditions for long-term environmental policy integration in Swedish regional development programming ' Journal of Environmental Planning and Management, 57(7), pp. 1023-1042.

Tornberg, P. 2011. Making sense of integrated planning: challenges to urban and transport planning processes in Sweden. (Diss.) Royal School of Technology, Stockholm.

SCC (Stockholm County Council). (2010) Regional Development Plan for Stockholm. Stockholm County Council, The Office of Regional Planning, Stockholm.

SRA (Swedish Road Administration). (2001). Effektivare nord-sydliga förbindelser $i$ Stockholmsområdet. Förstudie - Förslagshandling December 2001. Vägverket, Region Stockholm Övr 2001:0152. Vägverket, Solna. (In Swedish).

SRA (Swedish Road Administration). (2005) Nord-sydliga förbindelser i Stockholmsområdet. Vägutredning, Utställelseversion juni 2005. Objektnummer 48590. Vägverket, Solna. (In Swedish)

SRA (Swedish Road Administration). (2008) Vägverkets yttrande inför tillåtlighetsprövning enligt 17 kap. MB. Effektivare Nord-Sydliga Förbindelser i Stockholmsområdet. 2008-05-19. Dnr PP 20 A 2006:27366, Vägverket, Solna. (In Swedish)

SRASt (Swedish Road Administration, Region Stockholm). (2005) Miljökonsekvensbeskrivning. Vägutredning Nord-Sydliga förbindelser i Stockholmsområdet. Utställelseversion juni 2005, objektnummer 48590, Vägverket, Solna. (In Swedish)

Stockholmsförhandlingen (The Stockholm negotiation). 2007. Trafiklösning för Stockholmsregionen till 2020 med utblick mot 2030. (In Swedish)

Tengström, E. (1990) 'Bilsamhället: Bilens makt och makten över bilismen', in: Beckman, S. (ed.), Miljö, media, makt. Carlsson Stockholm, (in Swedish)

UN (United Nations) (2015) Adoption of the Paris Agreement.Proposal by the President. Draft Decision -/CP.21 Framework Convention on Climate Change, FCC/CP/2015/L.9/Rev.1, 12 December 2015.

WSP (2007) Konsekvensbedömningar av underlag till Stockholmsförhandlingens resultat. Stockholm: WSP Analys \& Strategi. (in Swedish) 